\title{
Dressing down criminals, deviants and other undesirables
}

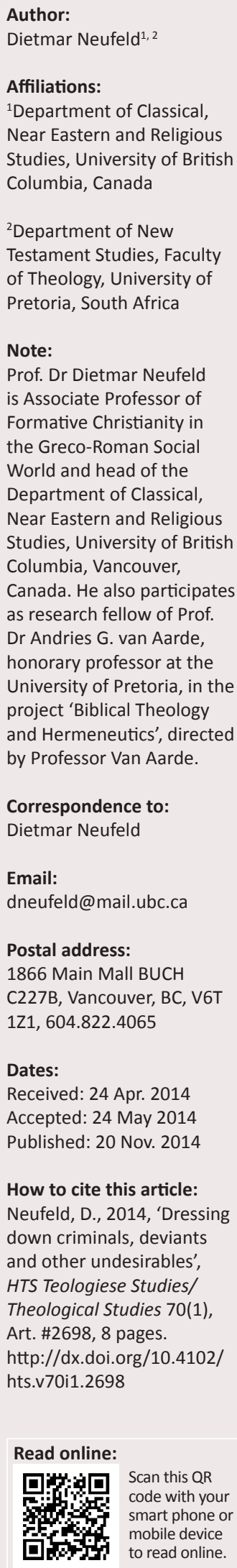

Fear of just censure and the sense of shame it produced kept Roman citizens from doing wrong (Cic. Rep. 5.6). Invective functioned socially as a strategy of social sanction. One amongst a number of commonly identified topics of accusation in the Roman tradition of ridicule was unusual appearance, clothing or demeanour. Not surprisingly, John the Baptist emerges from the desert attired distinctly, demoniacs come out of the tombs so fierce that no one would pass by them (Mt 8:28), a man with an unclean spirit lives amongst the tombs and, even though adorned with fetters and chains, cannot be controlled (Mk 5:15-20). Herod pretentiously puts on the royal robes and is eaten by worms and dies (Ac 12:21). A woman uninvited enters a rich man's dinner party with an alabaster flask of perfume and anoints the feet of Jesus (Lk 7:38). Clearly, in each case, unusual appearance, clothing, and demeanour suggest a lapse from the appropriate, socially acceptable style of deportment and clothing. Oddities in dress and demeanour were equated with oddities in behaviour and provided a powerful rhetorical means of excluding undesirables from society.

Know, first, who you are; and then adorn yourself accordingly. (Epictetus)

Stripped of the cunning artifices of the tailor, and standing forth in the garb of Eden - what a sorry set of roundshouldered, spindle-shanked, crane-necked varlets would civilized men appear! (Herman Melville 1996)

\section{Introduction}

\section{Attracting attention: The dress of mockery and the mockery of dress}

In her article on women living in Orthodox Israel, Zamkanei reports that in current Israel a new kind of war is being waged between conservative men who believe that women have no place in the public domain and women who disagree - this war of gender values is focused symbolically on the attire of women. On each side of the debate, deeply divided dress discourses represent the cunning exploitation of loci of control on issues of gender, sexuality, body, and rights to public space:

The aggressors argue that women's dress today is immodest and that modesty must be preserved in the public arena. Naked arms prompt thoughts of naked limbs; naked limbs, naked sex. And men who think about sex with strangers are men who cannot possibly focus on learning the laws of a good, moral life. (Zamkanei 2012)

Clearly, this focus upon women's dress is the crucible where gender, virtue and authority simmer and boil over. In the words of Greenblatt (1908:1), 'the power to impose a shape upon oneself is an aspect of the more general power to control identity-that of others at least as often as one's own'. Recent studies have emphasised performance and self-styling through body language and modifications, that is, focusing on the 'dynamics by which the contour of the body as a being and a special agent is defined, maintained, transgressed or undone' (Cairns 2005:7). Cairns (2005) reminds us that social structures depend upon making distinctions and hierarchies between 'bodies' in terms of social status, gender, disability, deviancy, to name a few. Moreover, he says, social stability is dependent upon the creation and maintenance of social margins - which bodies belong where and what defines them - and the boundaries are exemplified by making distinctions between differing categories of bodies. The materiality of bodies and prescriptive behaviours brings into view these boundaries whilst transgressive conduct brings into view the prospect of a world of up-side-down boundaries of criminals, deviants and undesirables (Cairns 2005). The classifications of bodies is driven by the notion that outward adornment and visible bodily actions communicate particular messages about internal states and the disposition of bodies and their placement in the hierarchies of societal structures.

This article is about dressing the body up and down both literally and figuratively, and about criminality, deviancy and undesirability literally (as in criminals, deviants and undesirables) but

Copyright: @ 2014. The Authors. Licensee: AOSIS OpenJournals. This work is licensed under the Creative Commons Attribution License. 
also symbolically as in the qualities in behaviour reflected in each of these states that expressively mark their bodies; for example, the language of clothing penetrates our pithy sayings about internal states of thinking and feeling rising to the surface of the body that we either wish to cover up or wear in public. We speak of wearing our hearts on our sleeves, covering expressions on our faces, revealing the fabric of our souls, clothing ourselves with honour, thinly veiling our disappointments, baring our hearts, and masking our eyes to disguise internal states (anger, pity, grief, hypocrisy, hate and love). Cicero (106-43 CE) emphasises the natural correspondence between the outer appearance of humans and their internal nature:

Then [nature] shaped the facial features (speciem oris) in such a way that it represented in them the character hidden deep within. For the eyes tell with great clarity how we have been affected in our spirit, and that which is called our countenance (vultus) - and which is able to exist in no living thing other than human - reveals our character. (Leg. 1.27; cf. Corbeill 2004:30; Fogen \& Lee 2009:15-44) ${ }^{1}$

The pioneering 20th century fashion designer Coco Chanel once said that 'adornment is never anything except a reflection of the heart' (Krick 2000). As we shall show, in the ancient world, qualities of the mind and heart that departed from the norms of what were perceived appropriate expressions of bodily emotionality frequently received a dressing down (Braund \& Gill 1997; Braund \& Most 2004; Braund 1988; Corbeill 2004, 2008; Harris 2001; Hope 2007). Mockery in a culture of visibility and debilitating shame magnified the qualities of soul and body either well or poorly adorned - literally and figuratively (Barton 1993, 2001, 2002).

Dress is not limited to garments that drape the body, but as recent studies have shown, must be broadly defined to include hair style, men's facial hair, voluntary or involuntary baldness, jewellery, cosmetics, perfumes, creams, rouge, and lip colouring (Batten 2009, 2010; Edmondson \& Keith 2008:7). And even more broadly, at least for the purposes of this article, I shall include discussions of the emotions and gestures with which we adorn our faces, cheeks (sometimes unhappily), eyes, bodies, feet, fingers, and hands; ${ }^{2}$ for example, a finger 'flipping the bird' adorns the hand with movement rife with messages to be interpreted just as much as a finger adorned

\footnotetext{
1.Roman treatises on oratory set out the appropriate display of nonverbal bodily clues - voice, gesture, garb and expression - all of which of course represent an idealised vision and may not reflect what really happened on the ground in dail interactions. The idealisations, however, appear to have feet on the ground (but what does having feet on the ground mean?) reflecting a customary perspective. In the New Testament, outward bodily deportment also signified internal states that were utilised to draw margins between the lepers, sinners, prostitutes, Pharisees, Sadducees, Jesus and John the Baptist (Q 7:24b-27; Lk 7:24b-27; Mt 11:7-10 Thomas 78:1-3), Paul and the super-apostles, those in soiled cloths and those in white robes (Rv $3: 4-5)$, and so on.

2.A particularly graphic example of bodily movement in synchronicity with interna haughtiness is found in the Hebrew Bible: 'Because the daughters of Zion are haughty and walk with outstretched necks, glancing wantonly with their eyes, mincing along as they go, tinkling with their feet; the Lord will afflict with scabs the heads of the daughters of Zion, and the LORD will lay bare their secret parts. In that day the Lord will take away the finery of the anklets, the headbands, and In that day the Lord will take away the finery of the anklets, the headbands, and the crescents; the pendants, the bracelets, and the scarfs; the headdresses, the armlets, the sashes, the perfume boxes, and the amulets; the signet rings and nos rings; the festal robes, the mantles, the cloaks, and the handbags; the garments of gauze, the linen garments, the turbans, and the veils. Instead of perfume there wil be a stench; and instead of a sash, a rope; and instead of well-set hair, baldness; and instead of a rich robe, a binding of sackcloth; instead of beauty, shame' (Is 3:16-24).
}

with an engagement ring communicates meaning. Gestures, each unique to the body part that makes the movement, can be seen as accessorising the body similarly to the way the body is accessorised with cosmetics, jewellery, clothing, skin markings, et cetera. To be sure, gesture is the body and adornment is done to the body yet each in their own way also adorn the body to convey meaning, hide intention and fear, display status, and signal utter devotion. Gestures are body movements, sometimes involuntary sometimes strategic, to communicate feelings or intentions that both ancient and moderns closely scrutinise for meanings. Handheld accessories not only gave a sense of panache to the hand but also displayed a spirited style and self-confidence in the repose of the body. These accessories were important for the construction of personal and communal identity. Women holding mirrors and gazing into them signalled status and beauty whilst for men it did not and was frowned upon. Men holding up weaponry signalled courage and men holding up scrolls signalled literacy and education.

A face, perhaps more than any other part of the body, is the most difficult to control and monitor for what it reveals about internal states. We thus wear expressions on our faces designed to hide what it is that we are really feeling and thinking. Or, positive or negative attention frequently instigates the unbidden blush in both men and women - tellingly in the cheeks. Pliny the Younger once said that the cheeks are the locus of shame - it is here that the red of blush is revealed (Barton 2001:224). As we shall develop in this article, ancient Romans loved to be seen and in such a spotlight frequently wore bland or benign expressions on their faces so as not to betray their thoughts and feelings. Tacitus describes the circumspect crowd after the death of Germanicus (19 CE):

The consuls, the senate and a great part of the population filled the roadside, standing in scattered groups and weeping as they pleased. There was no adulation of the emperor in this since everyone knew that Tiberius was struggling to conceal his joy at the death of Germanicus. He and the Augusta [Livia] made no appearance in public. Either they considered it beneath their dignity to mourn openly, or feared that if all eyes studied their looks they would discern hypocrisy. (Hope 2007:176)

What one wore on one's face and body had to be carefully monitored because both were open to public inspection and interaction (Atkinson 2002; Jeffreys 2000). In other words, we use dress, adornment, and gesture to subvert, challenge and expand cultural categories of beauty, gender, disability, deviance, piety, to name a few (Upson-Saia 2011). Each posture seeks to attract attention to itself with the desire that the embodied posture will communicate the message it was intended to send - either in compliance to normative social expectations or as a challenge to them.

But not only that, peculiarities in ornamentation and style of attire permitted society to marginalise individuals out of step with the norms of the community, state, household and association. Identifying publically the deficiencies of persons in Roman society on the basis of dress and gesture provided potent rhetorical means for banishing those individuals 
from society. In the context of mockery, dress became a potent locus of accusation because attire often belied types of behaviour public invective was intended to control. The bulk of this article addresses peculiarities in dress and physical mannerisms that are interpreted as signs of deviancy and sets them within the context of mockery, visibility and debilitating shame. Each of these areas will be treated separately in order to create a social milieu in which labelling and the ridiculing of such peculiarities are socially acceptable means for the public castigation of opponents.

\section{Mockery}

Ill-timed laughter or an indelicate comment especially when focused on cherished values held about self-identify, religious identity or national identity have been known to cause estrangements, wars and murderous dictators seeking revenge. Mockery of adornment and bodily deportment was powerful and, as Mary Beard (2009) makes clear, was a favourite device used by tyrants to destroy the reputation of their enemies; ethnicity, she says, was always good for a laugh - something with which we are all too familiar (Beard 2009:2). Slurs about ethnic attire cut straight through to target negatively the uniqueness of groups and individual character traits, traditions, and customs. She recounts the incident of Roman ambassadors negotiating with the Greek city of Tarentum in the 3rd century BCE when ill-timed laughter by the Greeks derailed the negotiations. It was clear that the Romans were deeply insulted and out of revenge were driven to war with the Tarentines. Whilst a number of reasons have been posited for the outburst of derisive laughter from the Tarentines, the historian Dio Cassius laid the blame directly on the national dress of the Romans - the toga; ${ }^{3}$ he wrote that:

So far from receiving them decently, the Tarentines laughed scornfully $(\gamma \varepsilon \lambda \omega \tau \alpha)$ at their dress $(\sigma \tau \boxminus \lambda \eta \dot{v})$ and general appearance. It was the city garb, which we use in the Forum. And the envoys had put this on, whether to make a suitably dignified impression or out of fear - thinking that it would make the Tarentines respect them. But in fact groups of revellers jeered at them ... with one of these revellers, even going so far as to 'bend down and shit'all over the offending garment. (Barnes 2005:114-117)

Barnes (2005) remarks that Dio Cassius's own identification with the symbolic values of the toga is reflected in his language; indeed, Barnes writes that the Tarentines were:

$[T]$ oo foolish to realize that they were not watching comedy, but real ambassadors on a serious mission, and as a result they failed to appreciate the 'august' or 'awe-inspiring' character of the toga. (p. 114-116)

Postumius, one of the ambassadors, menacingly reprimands the Tarentines, 'laugh, laugh as long as you can. For long shall you weep when you wash this garment with your blood' (Barnes 2005:117).

Mockery was a potent social weapon because of its coercive and corrosive powers to cause shame (May 2002:198).

3.Polybius $(1.6 .5 ; 8.24)$ blamed Tarentum prosperity and the arrogance and licentiousness that it bred as causes for the war.

\section{Cicero notes that:}

The best citizens are not deterred (from disgraceful behaviour) by fear of a punishment that has been sanctioned by laws as much as by the sense of shame that has been instilled by nature and a kind of fear of just censure (vituperationis non iniustae). The founder of the state used public opinion to cause this sense of shame to grow and refined it through both established custom and training. As a result shame, no less than fear, keeps the citizen from doing wrong. (Cic. Rep. 5.6)

Hence, mockery's focus was something to be feared and avoided. As May (2002:199) notes, mockery takes its function from its goal: if the dread of blame fails to preserve order, the perceived violator becomes exposed to public ridicule and expelled from the community. In cultures where the dynamics of keeping or forfeiting status, casting doubt on the status of others, of suffering or avoiding shame, or of wielding mockery's public power to cause damage to others, escaping the shamefulness of exposure by avoiding it or by failing to reassert honour after experiencing the derision of one's foes led to the danger of becoming a laughing-stock (Halliwell 2008:25).

Mockery was a highly pliable and effective means of communication and hence crossed gender, socioeconomic, political, religious, ethnic and body boundaries with ease. Invective supplied proof and exercised real powers of persuasion; after all, the 'body' was its body of evidence and helped to identify persons unfit for the community (Corbeill 2002:199). Given the dynamic performative and interactive social modes of mockery, it became a stock mode of communication not only in the daily interactions of people but also in handbooks of rhetoric and the public invective of politicians seeking to undermine their opponents and to promote a new personal public identity for themselves. Cicero masterfully used political invective in the public arena (ed. May 2002). When Cicero first stepped onto the stage, Rome had already developed a long history of invective. Tapping into this tradition, Cicreo used it effectively to defend clients, attack enemies, shape state policies, and promote his public persona and that of others (ethos) (Corbeill 2002:198-199).

We have yet to mention ancient physiognomies, but these works made clear this body-society and internal-external relationship by assessing external bodily features and then passing judgement, often in stereotypically mocking ways, on whether the person was fit to belong in the mainstream of society (Malina \& Neyrey 1996). Moreover interpretations were also made of these external bodily signs and what characteristics they revealed internally. ${ }^{4}$

My point is that anything that stood out visibly on persona and body in terms of adornment, physical peculiarities, mannerisms, gestures, evil eye, and the like, potentially became the focus of inspection and invective (Garland 2010). Public shaming was the goal and its intention was to inspire fear in every member of Roman society. Watching and being watched were spectator sports with the full awareness that at some point you could become the spectacle in someone's eye.

4.See here the excellent discussions of the body-society split and gender in GraecoRoman society and early Christian discourse (Stichele \& Penner 2009). 


\section{Visibility}

Valuable recent studies have shown the significant role that the gaze or the penetrating look had in the self-definition or the annihilation and disregard of others (Fredrick 2002:216-235). ${ }^{5}$ Particularly significant in this regard is Barton's analysis of Rome's culture of visibility. Barton (2002:216-235) examines the social behaviour of the eye itself and helpfully explains what it meant for ancient Romans to live visibly under the constant gaze of others. Barton situates her discussion of being in the eyes of others in the context of honour and shame that in a culture of visibility took on special concern. The gaze of the other was ever present and inescapable - hiding from it would have raised suspicions about one's character and raised the spectre of more intense scrutiny. Rome was a culture of visibility or public prominence where everyone was easily noticed by and caught the attention of the public, groups of people, and individuals. Indeed, argued Barton (2002:220), 'being, in Roman culture, was being seen'. By this she means that the gaze performed the important social function of constituting the essential nature of Romans. Being seen carried enormous risks especially when being seen unaware, unexpectedly, intentionally, and calculatedly. Fully aware of the risk, however, those with a sense of honour and shame accepted the peril of being visible (Barton 2002:221). The thinking here was that one's nature required 'testing' and 'probing', to be real, actual and current. ${ }^{6}$ Barton (2002:221) observes that the spectator was, for the Romans, an inspector, judge and connoisseur, and in such roles they are meant to hear, behold, observe, see, think and judge.

That the Romans watched and measured each other's behaviour has important implications for our understanding of clothing and physical mannerisms. Whilst there was a real danger in being visible, observing what people wore and the physical mannerisms on display in daily life provided clues about their character. In a culture of seeing and being seen would they be proven persons of spectati veri - tested and found to be true in character or found to be deficient in character?

When honour and shame were on the line, the stakes of mutual watching were high indeed. Yet, in spite of the perils of visibility, Barton avers that Roman honour carried with it a willingness to be exposed and the shame that it might bring. An added dimension useful for our study is Barton's contention that persons of honour were willing to be exposed and ready to be shamed (Barton 2002:221). Persons with an awareness of shame confirmed this willingness to be shamed by calling upon witnesses to attend to their words, conduct and public demeanour (Barton 2002:221). Both the gods and others around these persons were called upon to be judges and spectators of oaths taken, words spoken, behaviour displayed, body adorned and action taken. It was a way of saying to those around you that one's words and

5.This volume uses the theoretical conceptions of the gaze of Laura Mulvey and Michae Foucault and film theory to illuminate the literature and visual imagery of Rome.

6.Barton (2002:221) points out that terminology such as these were used to describe the effect of visibility upon one's persona (porbatus, spectatus, expertus and argutus). actions were open to public exposure and would stand up to careful scrutiny. Barton (2002:221) avers that 'the presence of witnesses made ones' every move into a test'.

It was in such a context of witnessing and being witnessed that bodily ornamentation and physical mannerisms received careful assessment, interpretation and judgement for what they revealed or betrayed about the internal disposition of each person in Rome - from slaves and their courts of reputation, to men and women, elite and non-elite and their respective courts of reputation (Crook 2009; French 2002; Lendon 1997). The denizens of Rome were aware that clothing and bodily decorum were the externally visible markers of the paths of vice and virtue. What if, however, the fear of public chastisement drove the denizens of Rome to avoid extremes in behaviour by taking on a temperate or modest persona?

\section{Debilitating shame}

For both men and women with an appropriate sense of honour in a culture of visibility, the temptation to play it safe in terms of adornment and bodily demeanour to escape the withering eye of scrutiny was great. Debilitating shame led to social paralysis, impaired individuals' pronouncements of deliberate opinion upon persons, rendered individuals unable to say no, and created in them the fear of offending someone. Barton (2002:220) makes the point, however, that men and women who remained within the limits of safe dress and decorum and never broke the rules were despised. Persons too decorous in manner and conduct were regarded as weak and therefore of exhibiting a shameful persona emasculated of its powers of judgement. A balance was to be maintained between a style of shame that was able to withstand an ocular culture pressuring conformity to social expectations but also to surrender to the pressure of expectations when it was justifiably warranted. Modesty and self-control, whilst much written about as exemplary virtues, were also frowned upon when it prevented people from setting out and defending clear limits. Such shame was driven by a fearful, false modesty that prevented inhabitants of Rome from challenging the dress and bodily comportment of those, for example, in their kinship group or others around them. The fear prevented them from passing on their judgements because of the apprehension of offending others - this hesitancy was itself perceived to be shameful and hence constituted acting shamefully (cf. Cicero, De officiis I.24.84).

Quintilian observes that false modesty is shameful and unbecoming of Romans:

I say with some reluctance ... that even modesty ... a fault which is nevertheless an amiable one easily giving rise to virtues ... is on occasion an impediment to those virtues ... it is not probity that is the object of my criticism, but that modesty which is a form of fear deterring the soul from doing what it should, and resulting in confusion of mind, regret that our task was ever begun, and sudden silence. For who can hesitate to number among the faults a feeling that makes man ashamed to do what is right? (Barton 2002:220) 
Bashfulness made persons in antiquity easy marks because out of fear they could be pushed to hide what should be exposed, act against their own will and judgement, refuse to act and dress in extravagant ways, and to endure the painfulness of shame's spotlight. They lacked integrity because they were unable to balance the tensions of self-control and self-scrutiny required of shame and the stimulating aspect of shame pushing them beyond their limitations (Barton 2001:216-223, 2002).

\section{Deviancy in New Testament displays of bodily deportment and dress}

The cultural practices of mockery, visibility, adornment and inordinate modesty are reflected in the portrayal of key characters in the New Testament. They stand out noticeably in their adornment, physical movement of bodies, gestures and activities. And, as we shall see, each of them attracts attention in one way or another - they are seen and critically assessed, at times mockingly, by witnesses, yet they endure eagerly the testing of the spectators, and they are not inflicted with an inordinate sense of modesty. One thinks, for example, of John the Baptist and the woman (named Mary in John's account) pouring expensive perfume either on the head or feet of Jesus. Matthew's and Mark's version record the perfume ending up on Jesus' head, and in the version recorded by Luke and John the perfume ending up on Jesus' feet (Mt 26:6-13; Mk 14:3-9; Lk 7:36-50; Jn 12:3-7). Whilst the details vary between the different versions of the gospels, their detailed attention to the woman's bodily expressions nevertheless dovetail effectively with my interest in adornment and the manner in which we decorate our physical bodies through dress, movement and gestures. Details notwithstanding in each of the accounts, John and the woman act unabashedly in pursuit of a goal, noble or otherwise - as will be shown below.

\section{The woman and the alabaster flask of perfume}

Let us consider briefly the case of a woman's curious behaviour of smearing an expensive perfume on the head or feet of Jesus and the case of John the Baptist's appearance on the public stage with unusual attire, demeanour and diet, and levelling formal accusations against his listening audience. Firstly, the story of the woman in the Lukan version finds its setting at a dinner party (symposium) with the guests and Jesus reclining at the table of a prominent man - perhaps indicating a lavish meal. These kinds of meals generally followed two traditions: one, as predinner dishes were distributed the servants circulated to wash the hands and feet of the guests and anoint them with perfumed oils. This would aid relaxation and remove the odour of soiled feet. Secondly, once guests had been made comfortable the main meal was served (Malina \& Rohrbaugh 2003:127-128).

In such an intimate setting, we begin with the story of a woman showing up at the dining event uninvited and then proceeding to put on a display of bodily movement of an extraordinary kind. Luke, in particular, includes a number of striking poses that profile the body of the woman. Whilst we are not given clues about her attire, two features about her body, however, stand out. She holds in her hand an alabaster flask of perfume and her head holds a head full of hair - obviously thick, flowing, and loosened enough to wipe a pair of feet dry. More pertinent to the Markan and Matthean version, typically women unbound their hair and clothing during both periods of mourning and childbirth (Corbeill 2004:10). Indeed, all types of knots or binding were done away with including avoidance of binding feet (shoeless or bare feet), hair and breasts (Corbeill 2004:92). The gestures were integral to women's task of preparing the body for the funeral taken from a standard repertoire of funeral rituals that were at their disposal and that they learned through countless demonstrations; for example, young women would have learned that unbinding their hair and feet, and beating their breast were standard gestures in the mourning ritual (Corbeill 2004:84-88). Corbeill notes that the action of avoiding binding during periods of lamenting the dead was generally understood 'as a way of exposing women to the pollution of death or the malevolence of spirits' (Corbeill 2004:92).

Whilst not integral to the Lukan version but certainly essential to Matthew's and Mark's, the woman's gestures of anointing his body are directly linked to the demise of Jesus - actions that are intended to preview his impending death. To our sensibilities these seem to be peculiar actions on her part, but in antiquity it was not unusual to be thinking about an impending death and even enacting one's own funeral. Petronius provides an interesting example of the freed slave Trimalchio replaying his own funeral:

Meanwhile Stichus, bring me the clothes in which I mean to be carried out. And some ointment, and a sample from that jar which is to be poured over my bones ... I want to be carried out in splendour, so that everyone calls blessings down on me. At once he opened a jar of ointment and anointed us all and said, 'I hope that I shall like this as much when I'm dead as when living'. (Hope 2007:119)

The pre-enactment of Trimalchio's death occurs at a dinner party in which appropriate funeral attire, a jar of anointment, and an anointing set the stage for Trimalchio's funeral preview. Whilst the dinner party deteriorates into a debauched funeral spectacle for Trimalchio, some of the details match both Matthew's and Mark's versions and add verisimilitude to their accounts. Fascinating are the references to blessings being called down upon Trimalchio by everyone and to his wishes of getting as much pleasure in death as when alive from the blessings and anointing - acts designed to memorialise him. Rather than Jesus re-enacting his own death, however, both Mark and Matthew take it upon themselves to preview his death in the anointing as a warning to their audiences that they ought to prepare for his death. ${ }^{7}$

The second feature of the woman's bodily profile is the flask

7. Horsley $(2001: 207-208 ; 217-218)$ is of the opinion that the anointing signals the 'Christ-ing' of Jesus. Gundry (1993, 2003:142) disagrees and argues that the anointing signals a burial where perfume plays a significant role in preparing the body for burial. 
of ointment in her hand. I am suggesting that the flask in hand should be taken as an expensive decorative accessory similar to rings and other ornamental accoutrements of hand and figures (Archer, Fischler \& Wyke 1994; Wyke 1994). ${ }^{8}$ And, as hand and finger accessories are designed to do, the flask completes the image of her bodily posture, capturing the act of breaking the flask and of releasing the flow of perfume over the feet of Jesus - each gesture was a vivid display of devotion that ends in her status reinstatement. In a culture of visibility, the male and female guests in the room would have noticed every detail: her eyes adorned with tears, her tears wetting the feet of Jesus, her unbound hair drying his feet, her hand holding a flask of perfume, her hand breaking it, her hand wiping sweet-smelling oil on the feet of Jesus, and her lips kissing them. The kiss on the feet was an extravagantly expressive gesture belonging to the woman. How would the dinner guests have interpreted the spectacle of this woman kissing the feet of Jesus $?^{9}$ They may have perceived the kiss as a kind of riposte that condemned the host and exposed him to the shame of public embarrassment - he was a lousy host because he had neglected his duties of hosting a proper dinner party. Perhaps this kiss was no more than the woman enacting a task that should have been undertaken by the host. Yet, a kiss between relations of honour was not unusual. Herodotus mentions that it was customary to kiss people to whom you wished to show honour - it was a clue to honour relations:

When they meet each other in the streets, you may know if the persons meeting are of equal rank by the following token: if they are, instead of speaking, they kiss each other on the lips. In the case where one is a little inferior to the other, the kiss is given on the cheek; where the difference of rank is great, the inferior prostrates himself upon the ground. (Malina \& Rohrbaugh 2003:378)

The kiss thus seems to be more than the woman just criticising the domestic lack of responsibility of the host - the kiss may have been a show of status demarcation - he superior and she inferior. Luke's version states that she did not stop with the one kiss but kept repeatedly kissing them.

Based on what the guests saw in the decorum of her body they would probably have drawn the conclusions that she lacked the type of shame an honourable woman should have exhibited. In this instance, however, they got it all wrong. Her gestures signalled her intention to break the rules of appropriate public decorum - obviously she was not inhibited in any way by bashfulness but as a person of honour was sensitive to shame and willing to suffer for it. Her shame was not driven by a fearful, false modesty that prevented her from challenging the dinner guests. The gestures of her body without a doubt captured the attention and commentary of the dinner guests in the house all the more so because we

8.Wyke's (1994:143) discussion of toiletry articles and women in the Roman world caskets, mirrors and women's ornaments - concludes that the items 'literally display the adorned female body as a crafted object'. By what is held and handled in the hand, the bodies of women are visibly rendered in a variety of ways.

9.Commentators are uncertain about how to understand the action of her lips kissing

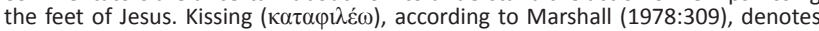
deep retverence such as paid to teachers. Gundry (2010) suggests that her kissing the feet of Jesus shows worshipful affection. Malina and Rohrbaugh (2003:378) show that act of kissing and the meaning it conveys varies: romance (Song 1:2 7:9; 8:1), seduction ( $\operatorname{Pr} 7: 13)$, deference (Sir 29:5), kinship (Gn 27:27; 29:11, 13), 7:9; 8:1), seduction ( $\operatorname{Pr} 7: 13)$, deference (Sir 29:5), kinship (G
friendship (1 Sm 20:41), peace (Ps 85:10), betrayal (Mk 14:44). are informed in Luke's version that she was a woman of the city and a sinner. In this instance, however, the reminder of her city origins or her character as sinner were not important because the graphic gestures of a body in which eyes, hands, body, head and hair, and lips enacted her utter devotion to Jesus without giving a care about public appearances.

Luke comments that the dinner host, who had invited Jesus, upon observing her bodily gestures, immediately thinks to himself that her body language verifies what he supposes she is - a woman of dubious reputation. The dinner host sniggers to himself that implicates both the woman and Jesus: 'If this man was a prophet, he would have known who and what kind of woman this is who is touching him - that she is a sinner' (Lk 7:39). The internal snort was laced with disdain at the serious party blunder of Jesus with the intention of shaming Jesus in public. ${ }^{10}$ And, her exhibition of bodily gestures before males and females at a dinner party suggested that she scorned the law and the limit of her nature (Corbeill 1996:98). ${ }^{11}$ The host was aware that bodily gestures were part of his cultural system where what her body portrayed externally in terms of dress and movement corresponded internally with her nature - perhaps indicating that she was a woman of bad character. He may have also been thinking that in her case, a show of bashfulness before those who were observing might have saved her reputation, Jesus' - and perhaps his. Moreover, based on scrutinising her extravagant bodily gestures, Jesus the prophet should also have recognised the character of the woman touching him and presumably avoided her touch (Lk 7:39). A host thinking such thoughts, however, a bad guy they did not make him. These thoughts were natural responses for someone embedded in a system of seeing, being seen, and connecting what was observed on the surface of the body with what it revealed about the internal disposition of the one on spectacle.

Whilst the responses were predicable, it is clear that some of the guests and the host of the dinner party nevertheless did not correctly read her gestural language and assumed that her behaviour confirmed what they suspected her of being - a woman of ill repute (Lk 7:39). In each of the Gospels this social phenomenon of interpreting her body language towards Jesus plays the important role of juxtaposing the misguided interpretations of the suspicious onlookers with the woman's genuine albeit audacious expressions of body. Their timidity limited them to consider the mundane options only; she should have peddled her oil to help the poor. They did not consider that her unabashed gestures signalled exotically the mourning of Jesus in advance of his burial an act of unreserved fidelity that memorialises her. Mark informs us that they censured her for not having hawked her

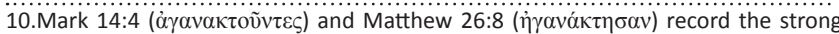
negative reaction of the disciples in Mark's version and of some guests in Matthew's. They are angry and in the ancient world anger was an emotion that lashed out in invective intended to destroy reputations. Mark adds that she was sharply rebuked with a hint of scorn in the reprimand (Mk 14:5).

11.Cicero writes: ' $[A]$ and as for how someone walks and sits, or the type of facial features and expressions each person has - is there nothing in these matters that we consider and expressions each person has - is there nothing in these matters that we consider
either worthy or unworthy of a freeborn person? Isn't it true that we consider many either worthy or unworthy of a freeborn person? Isn't it true that we consider many
people worthy of our contempt who, through certain kind of movement or posture, seem to have scorned the law and limit of nature' (Corbeill 1996:98). 
oil for the poor - the tone of scorn is clear: '[W]ell she could have hawked the oil for more than three-hundred denarii and given the money to the poor' (Mk 3:5). In Luke, the incident sets the stage for the upbraiding or mockery of Simon for his lack of social propriety. In Luke's estimation, the host's bodily gestures, or the lack of them, reveal a series of serious social blunders. His lack of appropriate bodily gestures (no water for the feet, no kiss of greeting, no application of head oil) gave him away - it revealed an internal smug, condescension worthy of contempt.

\section{John the Baptist}

In the case of John the Baptist, clearly he was not inflicted with a bashful spirit. He is portrayed as proclaiming a message in the wilderness of Judea, adorned in a skirt of camel's hair, girded with a leather belt around his waist, and subsisting on a diet of locusts and wild honey (Mt 3:3-6; Mk 1:4-6; Lk 3:16; Thomas 78:1-3). Each of the gospels represents John and the desert in somewhat different ways. For our purposes, however, it does not matter whether he proclaimed in the desert, made a sudden appearance out of the desert as proclaimer, or heard the word of God in the desert. ${ }^{12}$ Each of these verbal sketches captures in words the distinct images of a solitary, singular figure emerging from the wilderness with either good news for those who follow him or bad news for those who do not. It is up the spectators, hearers, and readers to imagine what the desert as metaphorical or literal locality tells them about who this individual is. What is clear, the portrait hardly seems in a style of attire and movement of the physical body - its movement in the desert and the mouth 'as moral appearance in action' - that was intended to be camouflaged from public view (Corbeill 1996:99). Indeed, it was not at all the case that the activity and physique of John were to be hidden from public scrutiny - but why put him on view in such a striking manner?

Intriguing in this regard is Corbeill's study of bodily movement in ancient Rome and of mouths in action. He makes the point that the human physique shares actively in its context. This is especially the case when the locale of its activity is unusual, when the physique is adorned with uncommon attire, and when the mouth is ingesting food of an exotic kind whilst at the same time spitting out harsh words of judgement. Each of these three elements defines the specific characteristics of the environment of John but note as well the extent to which the physical body of John also participates in that environment. These physical movements when properly orchestrated, says Corbeill (2004:108), 'are able to influence and manipulate the morethan-human world'. We do not have the information about the style of walk John exhibited in public. For our purposes, however, we do not need to have precise descriptions of his walking style. On the basis of his attire, diet and fiery verbal communication, we can surmise what it might have been like - deliberate, uncompromising and fearless. Studies show

12.Each of the Gospels differs on the wilderness details. Mark situates John's appearance in the wilderness followed with a quotation from Isaiah, Matthew situates John preaching in the wilderness and then links him with the prophet Isaiah, and Luke situates John in the larger chronological flow of principle Roman rulers after which John receives the word of God in the wilderness. that dress and diet have profound influence on bodily gait, patterns of speech and physical demeanour. The Judeans under Rome's rule would have monitored movements such as walking - or the walk as reflected in the dress, diet and talk of John - because it would have represented a good source for evaluating John's thoughts, actions, and social status. We are accustomed to subverting, challenging, and expanding cultural categories of beauty, gender, disability, deviance and piety on the basis of what is worn by the object of our scrutiny - the beauty industry or homelessness are but two graphic examples.

In the case of John, his walk, so to speak, and the extension of his walk through adornment, diet, and speech gave him away. John's bodily make up was appropriate to his station in life - a prophet speaking uncompromising words of judgement on those promoting social inequities in society and other egregious behaviours not in keeping with appropriate domestic decorum (Lk 3:19; Mt 1:14). But, as we have pointed out what marks the surface of the body, perhaps manufactured for effect, does not always reveal one's true intention. John faces the same obstacles. He is seen, evaluated, and in John's account queried about who he really is (Jn 1:24-28; Mk 6:14-16; Lk 9:7-9). He was eventually arrested for meddling in the domestic affairs of Herod that on the basis of household intrigue culminated with his execution (Mt 14:1-12; Mk 6:14-29; Lk 9:7-9). Thus whilst a tragic death, the body of John in its covering and bodily gestures, however, served to confirm in the eyes of a spectating culture of a rebel not limited by a debilitating shame that was afraid to pronounce harsh words of truth in uncompromising terms: 'You brood of vipers! Who warned you to flee from the wrath to come?' (Lk 3:8).

\section{Conclusion}

In a culture of mockery and visibility and the potential loss of honour, an appropriate sense of shame went a long way in mitigating the danger of being made a spectacle in the eyes of the beholders. The body was the medium of communication because of the astonishing ways the body could be managed and manipulated through outer adornment and bodily mannerisms. Outward displays of the body accessorised and the internal states it revealed cohabited symbiotically as nodal points of communication. In a cultural system keenly sensitive to the body being read in the eyes of a spectating public outer décor and gestures were seen to function in concert to reveal embodied nature. Seeing and being seen established or destroyed reputations. It was the willingness to suffer the shame of exposure whilst also controlling bodily decor or movement in public that provided a modicum of protection from the inquisitive eye and its judgement. ${ }^{13}$ Given the daily face-to-face interactions of Romans, Roman invective frequently focused on bodily movement as readable signs that pointed to the character and moral disposition of the inhabitants of Rome.

Reading the external bodily signs for information about

13.The nouns of aspectus, os, vultus and verbs such as video dominate Roman oratory (Corbeill 2004:147). 
inward temperament and disposition, however, was a tricky business at times; for example, that John the Baptist did not dress in the soft robes and fine clothing of those living in luxury nor in royal palaces but in the attire befitting an uncompromising prophet confused some of those evaluating him. Yet some of the crowds did not seem to get him-Matthew and $Q$ have Jesus censure them - what did you expect? Did you go out the desert to observe a reed shaken in the wind (Mt 11:7, 8; Q 7:24-28; Q7:33)? Moreover, it also appears as if his eating and drinking habits were misread to implicate him of having a demon (Mt 11:16-19; Q 7:31-35). Similarly, the woman at the dinner party suffered from the guests misreading her intentions based on her outer decoration and bodily movement and passing judgement on her character. Her unabashed behaviour eventually condemned those in attendance for being too bashful in their willingness to endure the painful consequences of shame - they were the ones who lacked honour and integrity and not she (Barton 2001:221).

\section{Acknowledgements \\ Competing interests}

The author declares that he has no financial or personal relationship(s) that may have inappropriately influenced him in writing this article.

\section{References}

Archer, L.J., Fischler, S. \& Wyke, M. (eds.), 1994, Women in ancient societies: An illusion of the night, Routledge, New York.

Atkinson, M. 2002, 'Pretty in ink: Conformity, resistance, and negotiation in women's tatooing', Sex Roles 47(5/6), 219-235. http://dx.doi.org/10.1023/A:1021330609522

Barnes, C.L.H., 2005, Images and insults: Ancient historiography and the outbreak of the Tarentine War, Franz Steiner, Stuttgart.

Barton, C.A., 1993, The sorrows of the ancient romans: The gladiator and the monster, Princeton University Press, Princeton.

Barton, C.A., 2001, Roman honor: The fire in the bones, University of California Press, Berkeley.

Barton, C., 2002, 'Being in the eyes: Shame and sight in ancient Rome', in D. Fredrick (ed.), The Roman gaze: Vision, power and the body, pp. 216-235, Johns Hopkins University Press, Baltimore.

Batten, A.J., 2009, 'Neither gold nor braided hair (1 Tim 2:9; 1 Pet 3:3): Adornment, gender and honour in antiquity', New Testament Studies 55(4), 484-501. gender and honour in antiquity', New Testa
http://dx.doi.org/10.1017/S0028688509990075

Batten, A.J., 2010, 'Clothing and adornment', Biblical Theology Bulletin 40(3), 148-159. http://dx.doi.org/10.1177/0146107910375547

Beard, M., 2009, 'What made Greeks laugh?', The Times Literary Supplement, 18 February, 1-7.

Braund, S.M., 1988, Beyond anger: A study of Juvenal's third book of Satires, Cambridge University Press, Cambridge.

Braund, S.H. \& Gill, C. (eds.), 1997, The passions in Roman thought and literature Cambridge University Press, Cambridge. http://dx.doi.org/10.1017/CBO97 80511586163

Braund, S.H. \& Most, G.W., 2004, Ancient anger: Perspectives from Homer to Galen, Cambridge University Press, Cambridge. http://dx.doi.org/10.1017/ CBO9780511482120
Cairns, D.J., 2005, Body language in the Greek and Roman worlds, Classical Press of Wales, Swansea.

Corbeill, A., 1996, Controlling laughter: Political humor in the late Roman Republic, Princeton University Press, Princeton.

Corbeill, A., 2002, 'Ciceronian invective', in J.M. May (ed.), Brill's companion to Cicero: Oratory and rhetoric, pp. 197-217, Brill, Leiden. http://dx.doi. org/10.1163/9789047400936_008

Corbeill, A., 2004, Nature embodied: Gesture in ancient Rome, Princeton University Press, Princeton.

Corbeill, A., 2008, 'Death in ancient Rome: Book review', American Historical Review 113(5), 1590-1591. http://dx.doi.org/10.1086/ahr.113.5.1590

Crook, Z., 2009, 'Honor, shame, and social status revisited', Journal of Biblical Literature 128(3), 591-611.

Edmondson, J.C. \& Keith, A., 2008, Roman dress and the fabrics of Roman culture, University of Toronto Press, Toronto.

Fogen, T. \& Lee, M.M. (eds.), 2009, Bodies and boundaries in Graeco-Roman antiquity, De Gruyter, Berlin.

Fredrick, D. (ed.), 2002, The Roman gaze: Vision, power, and body, Johns Hopkins University Press, Baltimore.

French, P.A., 2002, 'Honour, shame, and identity', Public Affairs Quarterly 16(1), 1-15.

Garland, R., 2010, The eye of the beholder: Deformity and disability in the Graeco-Roman world, 2nd edn., Bristol Classical, London.

Greenblatt, S., 1908, Renaissance self-fashioning from More to Shakespeare, University of Chicago Press, Chicago.

Gundry, R.H., 1993, Mark: A commentary on his Apology for the Cross, William B. Eerdmans Publishing Company, Grand Rapids.

Gundry, R.H., 2003, 'Richard A. Horsley's hearing the whole story: A critical review of its postcolonial slant', Journal for the Study of the New Testament 2(26), 131-149. http://dx.doi.org/10.1177/0142064X0302600201

Gundry, R.H., 2010, Commentary on Luke, Baker Academic, Grand Rapids.

Halliwell, S., 2008, Greek laughter: A study of cultural psychology from Homer to early Christianity, Cambridge University Press, Cambridge. http://dx.doi.org/10.1017/ CBO9780511483004

Harris, W.V., 2001, Restraining rage: The ideology of anger control in classical antiquity, Harvard University Press, Cambridge.

Hope, V.M., 2007, Death in ancient Rome: A source book, Routledge, New York.

Horsley, R.A., 2001, Hearing the whole story: The politics of plot in Mark's Gospel, Westminster, Louisville.

Jeffreys, S., 2000, 'Body art and social status: Cutting, tatooing, and piercing from a feminist perspective', Feminism \& Psychology 10(4), 409-429. http://dx.doi. org/10.1177/0959353500010004002

Krick, J., 2000, 'Gabrielle "Coco" Chanel (1883-1971) and the House of Chanel', in Heilbrunn Timeline of Art History, The Metropolitan Museum of Art, New York.

Lendon, J., 1997, Empire of honour, Oxford University Press, Oxford.

Malina, B.J. \& Neyrey, J.H., 1996, Portraits of Paul: An archaeology of ancient personality, Westminster, Louisville.

Malina, B.J. \& Rohrbaugh, R.L., 2003, Social science commentary on the Synoptic Gospels, 2nd edn., Fortress, Minneapolis.

Marshall, I.H., 1978, Commentary on Luke, William B. Eerdmans Publishing Company, Grand Rapids.

May, J.M. (ed.), 2002, Brill's companion to Cicero: Oratory and rhetoric, Brill, Leiden. Melville, H., 1996, Typee: A peep at Polynesian life, Penguin Classics, New York.

Stichele, C.V. \& Penner, T., 2009, Contextualizing gender in early Christian discourse, T \& T Clark, New York.

Upson-Saia, K., 2011, Early Christian dress: Gender, virtue and authority, vol. 3, Routledge, New York.

Wyke, M., 1994, 'Woman in the mirror: The rhetoric of adornment in the Roman world', in L.J. Archer, S. Fischler \& M. Wyke (eds.), Women in Ancient Societies: 'An illusion of the night', pp. 134-151, Routledge, New York.

Zamkanei, S., 2012, 'What next for Israel's Orthodox women - The burka?' in The Huffington post, viewed 05 February 2012, from http://www.huffingtonpost.ca/ shayna-zamkanei/israel-women-attack_b_1234622.html?ref=canada 